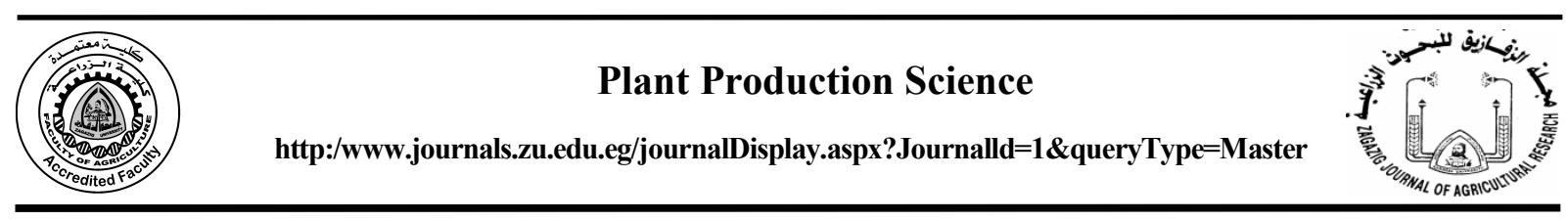

\title{
APPROACH FOR MINIMIZING THE AMOUNT OF MINERAL FERTILIZERS FOR MANFALOTY POMEGRANATE TREES USING MYCORRHIZA AND YEAST EXTRACT
}

\author{
Ahmed M. A. Sharawy", Safaa A. Nomier, M.M. Ibrahim and M.M. Gad \\ Hort. Dept. Fac. Agric., Zagazig Univ., Egypt
}

Received: 21/10/2018 ; Accepted: 25/11/2018

\begin{abstract}
A field experiment was carried out on 6-year-old Manfaloty pomegranate trees grown in sandy soil at $3 \times 5 \mathrm{~m}$ under drip irrigation system in Abo-Hamad Distrect, Sharkia Governorate, Egypt, during the two successive seasons of 2015 and 2016. Thirty-three trees were subjected to 11 mineral fertilization treatments with or without mycorrhiza or yeast extract. Control trees fertigated by $100 \%$ mineral NPK without mycorrhiza or yeast extract addition. Other combinations were 75,50 and $25 \%$ mineral NPK with or without $30 \mathrm{~g}$ mycorrhiza or yeast extract. The mineral fertilizer and died yeast applied by fertigation in ten doses during the season, while mycorrhiza was applied to the soil in the wet region under the drippers at the first season (late of February) in the two seasons. The obtained results showed that the highest yield (38.85 and 24.76 $\mathrm{kg} /$ tree), average fruit weight (462.70 and $462.10 \mathrm{~g}$ ), fruit firmness $\left(759.90\right.$ and $\left.765.50 \mathrm{~g} / \mathrm{cm}^{2}\right)$, number of grains/fruit (630.70 and 484.20 grain) and grains weight (227.70 and $213.50 \mathrm{~g}$ ) were gained by trees fertilized by $25 \%$ mineral NPK $+30 \mathrm{~g}$ mycorrhiza/tree in the both seasons, respectively. The produced fruits on trees of this treatment contained higher TSS/acid ratio and total anthocyanin content. The trees fertilized by $75 \%$ mineral NPK $+30 \mathrm{~g}$ mycorrhiza / tree exhibited higher fruit retention percentages $(92.34$ and $88.70 \%)$ in the two seasons, respectively without significant differences between them in most cases. Leaves of trees fertigated by $100 \%$ mineral/tree (control) contained the highest values of $\mathrm{N}, \mathrm{P}, \mathrm{K}, \mathrm{Ca}$ and $\mathrm{Mg}$ in the both seasons. The results of this study showed that it is possible to saving $50-75 \%$ of mineral fertilizers with obtaining higher yields with better fruit quality by adding the mycorrhiza at $30 \mathrm{~g} /$ tree.
\end{abstract}

Key words: NPK fertilization, Manfaloty pomegranate, fertigation, mycorrhiza, yeast extract, fruit retention yield .

\section{INTRODUCTION}

Manfaloty is considered one of the most important pomegranate cvs grown successfully in Egypt. The total acreage of pomegranate in Egypt reached 34450 fad., out of them 11752 fad., is fruitful producing about 106260 tons with an average of 9.42 tons/fad. (Statistics of the Ministry of Agriculture, 2015).

Pomegranate trees can be grown in tropical to hot temperate climates. However the best pomegranate fruit quality is produced in regions with cool winters and hot dry summer (Sheets $\boldsymbol{e t}$ al., 2008). Recently, there has been an

\footnotetext{
Corresponding author: Tel. : +201282496147
}

E-mail address: ahmedalsharawy@yahoo.com increasing demand for pomegranate (Punica granatum L.) to meet the need of local as well as the foreign markets of some European and Arabic countries. Nowadays a great attention is focused on minimizing the intensive amounts of mineral fertilizers, because of their harmful effect and high costs. Although pomegranate trees can survive and grow under low soil fertility and water availability conditions, many research studies have been indicating that improving soil fertility and satisfying water requirement are essential factors to obtain a high production. However, increasing pomegranate tree productivity under desert conditions must 
be based on appropriate technical and economic management to the natural resources scarcity.

Fertilization programs are very important for the production of pomegranate fruits since it improves the fruit quality and packable yield and reduces the production costs and environmental pollution. Chemical fertilizers are an indispensable in fruit crop nutrition, but excessive and indiscriminate use of chemical fertilizers has deleterious effects on soil, water and atmosphere pollution, and reflected on animal and human health, it had also adversely affected the soil fertility, water quality, yield and quality of the products (Srivastava, 2012). Therefore, biofertilizers has assumed great importance for sustainable production and to improve the soil physical, chemical and biological properties, also biofertilizers is a good alternative to reduce uses of chemical fertilizers. Biofertilizers proved to eliminate the use of pesticides sometimes, and rebalance the ratio between plant nutrients in soils. Biofertilizers are easy and safe to handle with field applications improved their efficiency in increasing crop yields and decreasing the costs of some agricultural practices. It is worthy to state that biofertilizers do not replace mineral fertilizers, but significantly reduce their rate of application (Saber, 1993). The use of biofertilizers in enhancing plant growth and yield has gained momentum in recent years because of higher cost and hazardous effect of chemical fertilizers (Aseri et al., 2008). Recently, the yeast extract and Mycorrhizal fungi as a natural bio-stimulant are safety and natural substances using to improve plant growth, yield and quality of many crops. They are safe for human and environment. Bio-fertilizers have been extensively used as an eco-friendly approach to minimize the use of chemical fertilizers, improve soil fertility status and for the enhancement of crop production by their biological activity in the rhizosphere (Kannaiyan, 2002).

Yeast extract (Saccharomyces cervisiae, L) is considered as one of the promising bio-fertilizers for many crops. The higher positive action of yeast extract on growth and fruiting of fruit crops might be ascribed to its higher content of natural plant growth regulators (IAA, GA3, cytokinins), vitamins B, protein, amino acids as Arginine, Histidine, Isoleiucine, Leucine, Lysine, Methionine,
Cysteine, Phenylalanine, Tyrosine, Serine, Valine, Threonine, Tryptophan, minerals such as $\mathrm{N}, \mathrm{P}$ and $\mathrm{K}$, nucleic acid, glutathione, lecithine, enzymes, and coenzymes. Also, it is essential for the synthesis of amino lenulinic acid (AA) and protoprophyrin the precursor of chlorophylls and in activating photosynthesis through enhancing the release of carbon dioxide (Barnett et al., 1990). In addition, application of active dry yeast extract is very effective in releasing $\mathrm{CO}_{2}$ which improves net photosynthesis (Attala et al., 2000; Abd ElMoniem et al., 2002).

Micro-organisms such as mycorrhiza are present in most organic fertilizers with its beneficial effect on the uptake of most nutrient elements, besides improving the microbiological activity in the rhizosphere (Kohler et al., 2007). The arbuscular mycorrhizal (AM) symbiosis is an association between the roots of higher plants and soil fungi that promotes plant development, especially under suboptimal growth conditions (Koltai et al., 2010). Mycorrhiza can increase the absorption of non-mobile elements through external hyphae (Abdul Jaleel et al., 2007). Many studies on plants such as apple (Branzanti et al., 1992), Prunus avium L. (Arines and Ballester 1992), Vitis vinifera $\mathrm{L}$. (Singh et al., 2004), Banana cv. Grade Naine (Rodriguez-Romero et al., 2005) and pomegranate (Singh et al., 2012) have utilized AMF to increase the growth rate and nutrient uptake of plantlets.

The main target of this study is mainly to reduce the amount of chemical fertilizers and evaluate its effect with mycorrhiza and yeast extract treatments on yield and fruit quality of pomegranate Manfaloty cv. trees under the new reclaimed land conditions.

\section{MATERIALS AND METHODS}

This investigation was carried out through two successive seasons of 2015 and 2016 on 6year-old Manfaloty pomegranate trees (Punica granatum). The trees were grown in a private orchard located at Wady El-Mollak region, AboHamad Distrect, Sharkia Governerate. The trees were planted at $3 \times 5 \mathrm{~m}$ apart, in sandy soil under drip irrigation system. 
All trees were supplied with recommended ammonium nitrate $(33.5 \% \mathrm{~N})$ at $87 \mathrm{~kg} /$ fad./year, calcium super phosphate $\left(15.5 \% \mathrm{P}_{2} \mathrm{O}_{5}\right)$ at 23 $\mathrm{kg} /$ fad./year, potassium sulfate $\left(50 \% \mathrm{~K}_{2} \mathrm{O}\right)$ at 65 $\mathrm{kg} /$ fad./year, magnesium sulfate at $40 \mathrm{~kg} / \mathrm{fad} . /$ year and calcium nitrate at $41 \mathrm{~kg} / \mathrm{fad}$./year, in ten doses by fertigation during the season for mineral fertilizer. The experimental trees were healthy and approximately similar in growth vigor and size. The usual agriculture practices for pomegranate trees in the orchard were adapted to all trees, except those of fertilization treatments.

Arbuscular mycorrhizal (AM) was purchased from Microbiology Department, Agricultural Research Center (ARC), Egypt. The sample of $\mathrm{AM}$ was $30 \mathrm{~g}$ and added to $3 \mathrm{Kg}$ washed sand and it was dried for one day. AM and sand were mixed well together and applied under the tree until they reached to hair roots $(30 \mathrm{~cm}$ depth approximately), then the mixture was added in the wet region under the drippers. The application of mixture was at the first season (late of February) in the two seasons. As known, $1 \mathrm{~cm}$ of AM contains $10^{5}$ cells.

Died yeast (Saccharomyces cerevisae) was as a byproduct from a yeast Factory in Elobour City (Table 1). It applied in ten doses by fertigation during the season with mineral fertilizer.

Thirty-three pomegranate trees were chosen for this experiment. The selected trees were subjected to the following treatments as follows:

1. $100 \%$ mineral fertilizer (control).

2. $75 \%$ mineral fertilizer $+30 \mathrm{~g}$ arbuscular mycorrhiza (AM) / tree.

3. $50 \%$ mineral fertilizer $+30 \mathrm{~g} \mathrm{AM} /$ tree.

4. $25 \%$ mineral $+30 \mathrm{~g} \mathrm{AM} /$ tree.

5. $75 \%$ mineral fertilizer $+30 \mathrm{ml}$ yeast extract/ tree.

6. $50 \%$ mineral fertilizer $+30 \mathrm{ml}$ yeast extract/ tree.

7. $25 \%$ mineral fertilizer $+30 \mathrm{ml}$ yeast extract/ tree.

8. $75 \%$ mineral fertilizer $+30 \mathrm{~g} \mathrm{AM}+30 \mathrm{ml}$ yeast extract/tree.

9. $50 \%$ mineral fertilizer $+30 \mathrm{~g} \mathrm{AM}+30 \mathrm{ml}$ yeast extract /tree.
$10.25 \%$ mineral fertilizer $+30 \mathrm{~g} \mathrm{AM}+30 \mathrm{ml}$ yeast extract/tree.

11. $0 \%$ mineral fertilizer $+30 \mathrm{~g} \mathrm{AM}+30 \mathrm{ml}$ yeast extract / tree.

The experiment was set up in a randomized complete block design with three replicates, one tree per each. The responses of the tested trees to the applied fertilization treatments were evaluated through the following characteristics:

\section{Fruit Set Percentage}

Fruit set was record after $75 \%$ of petal fall. Date was tabulated as fruit set percentage of perfect flowers according to the following equation:

Fruit set $(\%)=\frac{\text { Number of set fruitlets }}{\text { Number of flowers }} \times 100$

\section{Fruit Weight (g)}

It was determined by 10 ripened fruits which were randomly collected from each replicate.

\section{Fruit Retention Percentage}

The numbers of remaining fruits at harvest date on the tagged shoots per tree were count in the end of each season. The percent of fruit retention was calculated according to the following equation:

Fruit retention $(\%)=$

$$
\frac{\text { Number of remaining fruits }}{\text { Number of set fruitlets }} \times 100
$$

\section{Yield/Tree (kg)}

At harvesting, on the late of Sept. and first of Oct. in the first and second seasons, respectively fruit weight $(\mathrm{kg})$ per tree was determined in each tree.

\section{Fruit Quality}

Fruit firmness $\left(\mathrm{g} / \mathrm{cm}^{2}\right)$ was determined by using a push pull Dynamometer. Grains weight (g), number of grains per fruit, fruit juice volume $\left(\mathrm{cm}^{3}\right)$ and TSS/acid ratio were calculated. Vitamin C (mg. ascorbic acid/100 ml juice) was determined by titration in presence of 2.6 - dichlorophenol-indophenol dye (AOAC, 2006). Total anthocyanin content (\%) was estimated according to the methods described by Geza et al (1983) 


\section{Leaf Mineral Content}

About $0.2 \mathrm{~g}$ of the finely ground dry matter of leaves of each replicate was digested in a mixture of concentrated sulfuric and perchloric acids $(2: 1 \mathrm{~V} / \mathrm{V})$ for 15 minutes until the digestive solution became colorless, then transferred quantitavely to $50 \mathrm{ml}$ volumetric flasks (Kitson and Mellon, 1964). The considered mineral nutrients were determined as follows:

Total nitrogen, phosphorus, potassium, calcium, magnesium were determined according to the standard method described by Evenhuis and Waard (1980).

\section{Statistical Analysis}

The obtained data was subjected to analysis of variances (ANOVA) according to Snedecor and Cochran (1980) using CO-STAT program. Differences between means were compared using Duncan's multiple range test at 0.05 level (Duncan, 1958).

\section{RESULTS AND DISCUSSION}

\section{Fruit Set Percentage}

Results in Table, 2 reveal that the fruit set (\%) of pomegranate trees cv. Manfaloty, generally, ranged from 21.86 to $30.11 \%$ in the first season and from 21.06 to $27.43 \%$ in the second one. The tested fertilization treatments significantly affected fruit set percentage in the two seasons. The trees fertilized by $0 \%$ mineral +30 g mycorrhiza $+30 \mathrm{ml}$ yeast extract recorded highest fruit set percentage $(30.11 \%$ and $27.43 \%)$ in the first and second seasons, respectively compared with other treatments. The other treatments gave insignificant values between them in the two seasons.

These results go in line with those reported by Soliman et al. (2017) on peach trees. They indicated that, Mycorrhiza increased fruit set percentage compared with control.

Bakry and Wanas (2003) on apricot, Bakry (2007) on orange and Hashem et al. (2008) on flame seedless Abd El-Motty et al. (2010) on mango and Shaaban et al. (2015) on apricot. They indicated that yeast extract increased fruit set percentage.

The positive effects of active dry yeast extract to increase fruit set could be considered as a natural source of cytokinins and improving net photosynthesis (Hashem et al., 2008). The constructive effect of spraying yeast extract could be also attributed to the enhancement of photosynthesis processes and increasing the promoter hormones as cytokinins (Kamelia $\boldsymbol{e t}$ al., 2000; Abd El-Galil et al., 2003) on "King Ruby" grapevines.

\section{Yield/ Tree}

As shown in Table 2 the tested fertilization treatments exhibited significant effect on fruit yield/tree $(\mathrm{kg})$ of pomegranate trees $\mathrm{cv}$. Manfaloty. Generally, it was ranged from 4.75 to $38.85 \mathrm{~kg}$ in the first season and from 9.50 to $24.76 \mathrm{~kg}$ in the second season. The trees fertilized by $25 \%$ mineral +30 g mycorrhiza/tree recorded uppermost fruit yield/tree $(38.85 \mathrm{~kg})$, followed by those fertilized by $75 \%$ mineral $+30 \mathrm{~g}$ mycorrhiza/ tree $(31.16 \mathrm{~kg})$ in the first season with significant differences between them. While in the second season, the uppermost values were from the trees fertilized by $100 \%$ mineral/tree (control) $(24.01 \mathrm{~kg})$ and those fertilized by 25 and $75 \%$ mineral $+30 \mathrm{~g}$ mycorrhiza/ tree $(24.76$ and $21.24 \mathrm{~kg}$ ) and also those fertilized by 75 and $25 \%$ mineral $+30 \mathrm{ml}$ yeast extract/tree $(22.71$ and $22.36 \mathrm{~kg})$ without significant differences between these treatments. Whereas, the trees fertilized by $0 \%$ mineral $+30 \mathrm{~g}$ mycorrhiza $+30 \mathrm{ml}$ yeast extract/tree $(4.75$ and $9.50 \mathrm{~kg})$ gave the least fruit yield/tree $(\mathrm{kg})$ in the two seasons, respectively. In addition, the trees fertilized by $75 \%$ mineral +30 g mycorrhiza/ tree and trees fertilized by $75 \%$ mineral $+30 \mathrm{ml}$ yeast extract/tree gave insignificant values of fruit yield/tree $(\mathrm{kg})$ between them in both seasons. The differences between treatments of trees fertilized by $50 \%$ mineral $+30 \mathrm{~g}$ mycorrhiza $+30 \mathrm{ml}$ yeast extract/tree (15.72 and $15.26 \mathrm{~kg}$ ) and trees fertilized by $25 \%$ mineral + $30 \mathrm{~g}$ mycorrhiza $+30 \mathrm{ml}$ yeast extract/tree $(15.06$ and $13.60 \mathrm{~kg})$ were insignificant in the two seasons.

These results are in line with those reported by Jansa et al. (2003) on pomegranate, Merwad et al. (2014) and Soliman et al. (2017) on peach trees. They revealed that, Mycorrhiza increased yield/tree compared with control.

Hence it is clear that mycorrhiza fungi play a vital role in nutrient cycling and productivity of crops (Lewis and Koide, 1990; Stanley et al., 1993; Smith and Read, 1997). Through appropriate management of mycorrhiza in agriculture, it is also possible to maintain soil quality and sustainability thereby protecting the environment over long term and also reducing cost of production. 
Table 1. Chemical analysis of died yeast solution

\begin{tabular}{|c|c|c|c|}
\hline Element & Concentration & Element & Concentration \\
\hline Total amino acid & $20 \%$ & Molybdenum (Mo) & $5.3 \mathrm{mg} / \mathrm{l}$ \\
\hline Free amino acid & $7 \%$ & Iron $(\mathrm{Fe})$ & $71.0 \mathrm{mg} / 1$ \\
\hline Nitrogen $(\mathbf{N})$ & $4.62 \%$ & Manganese (MN) & $11.3 \mathrm{mg} / 1$ \\
\hline Phosphorus $\left(\mathrm{P}_{2} \mathrm{O}_{5}\right)$ & $0.2 \%$ & $\operatorname{Zinc}(\mathrm{Zn})$ & $483.9 \mathrm{mg} / \mathrm{l}$ \\
\hline Potassium $\left(\mathbf{K}_{2} \mathbf{0}\right)$ & $9.8 \%$ & Copper $(\mathrm{Cu})$ & $5.3 \mathrm{mg} / 1$ \\
\hline Calcium (Ca) & $0.87 \%$ & Cytokines (CYT) & $762.6 \mathrm{mg} / \mathrm{l}$ \\
\hline Magnesium (Mg) & $0.16 \%$ & Gibberellin (Gib) & $495.2 \mathrm{mg} / \mathrm{l}$ \\
\hline Sulfur (S) & $10.04 \%$ & Boron (B) & $805 \mathrm{mg} / 1$ \\
\hline Organic matter & $59.75 \%$ & Organic carbon & $34.66 \%$ \\
\hline \multicolumn{2}{|c|}{ pH } & \multicolumn{2}{|c|}{7.23} \\
\hline
\end{tabular}

Table 2. Effect of mineral fertilizers with mycorrhiza and yeast extract treatments on fruit set, yield, fruit weight and fruit retention of Manfaloty pomegranate trees (2015 and 2016 seasons)

\begin{tabular}{|c|c|c|c|c|c|c|c|c|c|c|}
\hline \multicolumn{3}{|c|}{ Fertilization treatment } & \multicolumn{4}{|c|}{ First season (2015) } & \multicolumn{4}{|c|}{ Second season (2016) } \\
\hline $\begin{array}{c}\text { Mineral } \\
\text { (\%) }\end{array}$ & $\begin{array}{l}\text { AM } \\
(\mathbf{g} / \\
\text { tree }) \\
\end{array}$ & $\begin{array}{c}\begin{array}{c}\text { Yeast } \\
\text { extract } \\
(\mathrm{ml} / \text { tree) }\end{array} \\
\end{array}$ & $\begin{array}{c}\text { Fruit } \\
\text { yield/ } \\
\text { tree (kg) }\end{array}$ & $\begin{array}{c}\text { Fruit } \\
\text { set } \\
(\%) \\
\end{array}$ & $\begin{array}{c}\text { Av. Fruit } \\
\text { weight (g) }\end{array}$ & $\begin{array}{c}\text { Fruit } \\
\text { retention } \\
(\%)\end{array}$ & $\begin{array}{c}\text { Fruit } \\
\text { yield/ tree } \\
(\mathbf{k g})\end{array}$ & $\begin{array}{c}\text { Fruit } \\
\text { set } \\
(\%) \\
\end{array}$ & $\begin{array}{c}\text { Av. Fruit } \\
\text { weight } \\
\text { (g) }\end{array}$ & $\begin{array}{c}\text { Fruit } \\
\text { retention } \\
(\%)\end{array}$ \\
\hline 100 & $\mathbf{0}$ & $\mathbf{0}$ & 23.09 cde & $22.48 \mathrm{~b}$ & $300.50 \mathrm{de}$ & $88.18 \mathrm{ab}$ & $24.01 \mathrm{a}$ & $22.04 \mathrm{~b}$ & $304.90 \mathrm{~d}-\mathrm{g}$ & $90.60 \mathrm{a}$ \\
\hline 75 & 30 & $\mathbf{0}$ & $31.16 \mathrm{~b}$ & $21.86 \mathrm{~b}$ & $351.60 \mathrm{bcd}$ & $92.34 \mathrm{a}$ & $21.24 \mathrm{abc}$ & $22.98 \mathrm{~b}$ & $344.30 \mathrm{~cd}$ & $88.70 \mathrm{a}$ \\
\hline 50 & 30 & $\mathbf{0}$ & $20.91 \mathrm{def}$ & $22.63 \mathrm{~b}$ & $285.53 \mathrm{e}$ & $88.02 \mathrm{ab}$ & $17.20 \mathrm{bcd}$ & $23.55 \mathrm{~b}$ & 325.50 cde & $84.83 \mathrm{a}$ \\
\hline 25 & 30 & $\mathbf{0}$ & $38.85 \mathrm{a}$ & $22.52 \mathrm{~b}$ & $462.70 \mathrm{a}$ & $89.11 \mathrm{ab}$ & $24.76 \mathrm{a}$ & $23.46 \mathrm{~b}$ & $462.10 \mathrm{a}$ & $84.73 \mathrm{a}$ \\
\hline 75 & $\mathbf{0}$ & 30 & $29.01 \mathrm{bc}$ & $22.10 \mathrm{~b}$ & $366.00 \mathrm{bc}$ & $90.53 \mathrm{a}$ & $22.71 \mathrm{ab}$ & $22.35 \mathrm{~b}$ & $407.10 \mathrm{~b}$ & $86.95 \mathrm{a}$ \\
\hline 50 & $\mathbf{0}$ & 30 & $18.32 \mathrm{ef}$ & $22.78 \mathrm{~b}$ & $305.50 \mathrm{cde}$ & $88.18 \mathrm{ab}$ & $16.41 \mathrm{~cd}$ & $21.54 \mathrm{~b}$ & $321.60 \mathrm{c}-\mathrm{f}$ & $83.82 \mathrm{a}$ \\
\hline 25 & $\mathbf{0}$ & 30 & $26.61 \mathrm{bcd}$ & $24.93 \mathrm{~b}$ & $402.00 \mathrm{~b}$ & $87.24 \mathrm{ab}$ & $22.36 \mathrm{ab}$ & $21.06 \mathrm{~b}$ & $357.70 \mathrm{c}$ & $86.02 \mathrm{a}$ \\
\hline 75 & 30 & 30 & 24.01 cde & $21.87 \mathrm{~b}$ & $364.90 \mathrm{bc}$ & $90.21 \mathrm{a}$ & $16.13 \mathrm{~cd}$ & $22.13 \mathrm{~b}$ & 289.30 efg & $86.65 \mathrm{a}$ \\
\hline 50 & 30 & 30 & $15.72 \mathrm{f}$ & $23.65 \mathrm{~b}$ & 305.30 cde & $80.18 \mathrm{~b}$ & $15.26 \mathrm{~d}$ & $22.60 \mathrm{~b}$ & $278.80 \mathrm{fg}$ & 88.39 a \\
\hline 25 & 30 & 30 & $15.06 \mathrm{f}$ & $24.50 \mathrm{~b}$ & $351.00 \mathrm{bcd}$ & $79.99 \mathrm{~b}$ & $13.60 \mathrm{de}$ & $23.12 \mathrm{~b}$ & $302.20 \mathrm{~d}-\mathrm{g}$ & $86.45 \mathrm{a}$ \\
\hline $\mathbf{0}$ & 30 & 30 & $4.75 \mathrm{~g}$ & $30.11 \mathrm{a}$ & $229.06 \mathrm{f}$ & $66.12 \mathrm{c}$ & $9.50 \mathrm{e}$ & $27.43 \mathrm{a}$ & $262.80 \mathrm{~g}$ & $72.99 \mathrm{~b}$ \\
\hline
\end{tabular}


Bio-fertilizers are considered as a safe fertilization method to increase productivity and quality of many fruit species. Yeast extract as a bio-fertilizer is characterized by its own different nutrients, vitamins and cytokinin as a natural plant hormone and photosynthesis stimulator (Nagadawithana, 1991; Mostafa, 2015).

\section{Fruit Weight (g)}

The results presented in Table 2 show that fruit weight of Manfaloty pomegranate was significantly affected by the studied fertilization treatments during the two seasons. The uppermost values of fruit weight were from trees fertilized by $25 \%$ mineral +30 g mycorrhiza/ tree $(462.70$ and $462.10 \mathrm{~g})$ in the two seasons, respectively. While, the lowermost values of fruit weight were from trees fertilized by $0 \%$ mineral +30 g mycorrhiza $+30 \mathrm{ml}$ yeast extract/ tree $(229.06$ and $262.80 \mathrm{~g})$ in both seasons, respectively. The other treatments gained intermediate fruit weight without significant differences between them in most cases in both seasons.

These results are consistent with those obtained by Alok and Singh (2004) on banana, Abd-Ella (2006) on pomegranate, Gastol and Domagal-Swiatkiewiez (2015) on apple, El-Shamma et al. (2017) on avocado and Mohamed and Massoud (2017) on orange, they indicated that the use of mycorrhiza increased yield/tree and fruit weight.

Nomier (2000) on grapevines, Bakry and Wanas (2003) on apricot, Bakry (2007) on orange, Abd El-Monem et al. (2008) on grapevine, Abd El-Motty et al. (2010) on mango, Hegab et al. (2010) on grapevine, Khafagy et al. (2010) on orange, El-Sabagh et al. (2011) on grapevine, Osman et al. (2011) on date palm, El Shazly and Mustafa (2013) on orange, El-Sehrawy (2015) on apple and Shaaban et al. (2015) on apricot. They indicated that application of yeast extract increased the yield and fruit weight.

\section{Fruit Retention Percentage}

The results in Table 2 show that the pomegranate trees were significantly affected by the tested fertilization treatments on fruit retention percentage in both seasons. The values ranged from 66.12 to $92.34 \%$ in the first season and from 72.99 to $90.60 \%$ in the second one.
The highest fruit retention percentages came from the trees fertilized by $75 \%$ mineral $+30 \mathrm{~g}$ mycorrhiza /tree (92.34), followed by those fertilized by $75 \%$ mineral $+30 \mathrm{ml}$ yeast extract/tree $(90.53 \%)$ and trees fertilized by $75 \%$ mineral +30 g mycorrhiza $+30 \mathrm{ml}$ yeast extract/ tree $(90.21 \%)$ without differences among them in the first season. All tested fertilization treatments except treatment of $0 \%$ mineral $+30 \mathrm{~g}$ mycorrhiza $+30 \mathrm{ml}$ yeast extract/tree which recorded the highest fruit retention without significant differences among them during second season. While, the least values came from the trees fertilized by $0 \%$ mineral $+30 \mathrm{~g}$ mycorrhiza $+30 \mathrm{ml}$ yeast extract/ tree (66.12 and $72.99 \%)$ in both seasons.

Similar results was found by Mohamed and Massoud (2017) who found that AM with Azotobacter induced significant increment in growth criteria and yield attributes (fruit retained after June drop (\%), No. fruits/tree or $\mathrm{Kg} /$ tree) as compared to uninoculated control and biofertilizer only.

Bakry (2007) on orange, Abd El-Motty et al. (2010) on mango, and Shaaban et al. (2015) on apricot they indicated that yeast extract was effective in improving fruit retention.

\section{Fruit Firmness}

Results in Table 3, reveal that, fruit firmness $\left(\mathrm{g} / \mathrm{cm}^{2}\right)$ was significantly affected by the experimental fertilization treatments in the two seasons. Anyhow, the solidest fruit firmness was recorded for fruits produced from trees fertilized by $25 \%$ mineral $+30 \mathrm{~g}$ mycorrhiza/tree $(759.90$ and $765.50 \mathrm{~g} / \mathrm{cm}^{2}$ ) in the first and second season, respectively, without significant differences between those fertilized by $25 \%$ mineral $+30 \mathrm{ml}$ yeast extract/tree $\left(706.60\right.$ and $\left.654.40 \mathrm{~g} / \mathrm{cm}^{2}\right)$ and trees fertilized by $75 \%$ mineral $+30 \mathrm{~g}$ mycorrhiza $+30 \mathrm{ml}$ yeast extract/tree $(607.53$ and $664.40 \mathrm{~g} / \mathrm{cm}^{2}$ ) in both seasons. The lowest fruit firmness was recorded for fruits produced from trees fertilized by $0 \%$ mineral $+30 \mathrm{~g}$ mycorrhiza $+30 \mathrm{ml}$ yeast extract/tree $(295.50$ and $423.30 \mathrm{~g} / \mathrm{cm}^{2}$ ) in the two seasons. The other treatments gained intermediate fruit firmness $\left(\mathrm{g} / \mathrm{cm}^{2}\right)$ without significant differences among them in most cases in both seasons.

Similar results was found by Soliman et al. (2017), they found that using mycorrhiza produced solidest peach fruit compared with control. 
Table 3. Effect of mineral fertilizers with mycorrhiza and yeast extract treatments on fruit firmness, grains weight and number/fruit and Juice volume/fruit of Manfaloty pomegranate trees (2015 and 2016 seasons)

\begin{tabular}{|c|c|c|c|c|c|c|c|c|c|c|}
\hline \multicolumn{3}{|c|}{ Fertilization treatment } & \multicolumn{4}{|c|}{ First season (2015) } & \multicolumn{4}{|c|}{ Second season (2016) } \\
\hline $\begin{array}{l}\text { Mineral } \\
\text { (\%) }\end{array}$ & $\begin{array}{l}\text { AM } \\
(\mathrm{g} / \\
\text { tree })\end{array}$ & $\begin{array}{c}\text { Yeast } \\
\text { extract } \\
(\mathrm{ml} / \\
\text { tree) }\end{array}$ & $\begin{array}{c}\text { Fruit } \\
\text { firmness } \\
\left(\mathrm{g} / \mathrm{cm}^{2}\right)\end{array}$ & $\begin{array}{c}\text { Number } \\
\text { of grains/ } \\
\text { fruit }\end{array}$ & $\begin{array}{c}\text { Grains } \\
\text { weight (g) }\end{array}$ & $\begin{array}{c}\text { Juice } \\
\text { volume/ } \\
\text { fruit }\left(\mathrm{cm}^{3}\right)\end{array}$ & $\begin{array}{c}\text { Fruit } \\
\text { firmness } \\
\left(\mathrm{g} / \mathrm{cm}^{2}\right)\end{array}$ & $\begin{array}{l}\text { Number } \\
\text { of grains/ } \\
\text { fruit }\end{array}$ & $\begin{array}{c}\text { Grains } \\
\text { weight } \\
\text { (g) }\end{array}$ & $\begin{array}{c}\text { Juice } \\
\text { volume/ } \\
\text { fruit }\left(\mathrm{cm}^{3}\right)\end{array}$ \\
\hline 100 & $\mathbf{0}$ & $\mathbf{0}$ & $520.70 \mathrm{c}$ & $428.50 \mathrm{de}$ & $146.80 \mathrm{~d}$ & $201.60 \mathrm{abc}$ & $463.30 \mathrm{~cd}$ & $386.87 \mathrm{bc}$ & $142.60 \mathrm{ef}$ & $215.00 \mathrm{abc}$ \\
\hline 75 & 30 & $\mathbf{0}$ & $564.40 \mathrm{bc}$ & $506.10 \mathrm{bc}$ & $153.20 \mathrm{~d}$ & $240.00 \mathrm{a}$ & $564.40 \mathrm{bc}$ & $447.30 \mathrm{ab}$ & $154.80 \mathrm{de}$ & $256.66 \mathrm{a}$ \\
\hline 50 & 30 & $\mathbf{0}$ & $513.30 \mathrm{c}$ & $498.20 \mathrm{bc}$ & 152.90 cde & $213.30 \mathrm{a}$ & $576.60 \mathrm{bc}$ & $492.30 \mathrm{a}$ & $155.50 \mathrm{de}$ & $206.66 \mathrm{abc}$ \\
\hline 25 & 30 & $\mathbf{0}$ & $759.90 \mathrm{a}$ & $630.70 \mathrm{a}$ & $227.70 \mathrm{a}$ & $223.30 \mathrm{a}$ & $765.50 \mathrm{a}$ & $484.20 \mathrm{a}$ & $213.50 \mathrm{a}$ & $243.33 \mathrm{ab}$ \\
\hline 75 & $\mathbf{0}$ & 30 & $595.30 \mathrm{abc}$ & $494.40 \mathrm{bc}$ & $148.30 \mathrm{~d}$ & $171.60 \mathrm{bcd}$ & $571.00 \mathrm{bc}$ & $448.00 \mathrm{ab}$ & $206.60 \mathrm{ab}$ & $191.60 \mathrm{bcd}$ \\
\hline 50 & $\mathbf{0}$ & 30 & $545.50 \mathrm{bc}$ & $449.60 \mathrm{~cd}$ & $160.30 \mathrm{~d}$ & $163.30 \mathrm{~cd}$ & $542.20 \mathrm{bcd}$ & $341.80 \mathrm{~cd}$ & $176.60 \mathrm{~cd}$ & $193.33 \mathrm{bcd}$ \\
\hline 25 & $\mathbf{0}$ & 30 & $706.60 \mathrm{ab}$ & $523.60 \mathrm{~b}$ & $202.40 \mathrm{~b}$ & $205.00 \mathrm{ab}$ & $654.40 \mathrm{ab}$ & $353.00 \mathrm{~cd}$ & $197.10 \mathrm{ab}$ & $215.00 \mathrm{abc}$ \\
\hline 75 & 30 & 30 & $607.53 \mathrm{abc}$ & $401.90 \mathrm{def}$ & $188.50 \mathrm{~b}$ & $113.30 \mathrm{e}$ & $664.40 \mathrm{ab}$ & $312.33 \mathrm{~d}$ & $191.30 \mathrm{bc}$ & $196.66 \mathrm{bcd}$ \\
\hline 50 & 30 & 30 & $579.90 \mathrm{bc}$ & $373.00 \mathrm{ef}$ & $152.60 \mathrm{~d}$ & $136.60 \mathrm{de}$ & $592.20 \mathrm{bc}$ & $368.20 \mathrm{~cd}$ & $162.30 \mathrm{de}$ & $155.00 \mathrm{~d}$ \\
\hline 25 & 30 & 30 & $566.40 \mathrm{bc}$ & $466.40 \mathrm{bcd}$ & $174.40 \mathrm{c}$ & $145.00 \mathrm{de}$ & $495.50 \mathrm{~cd}$ & $336.20 \mathrm{~cd}$ & $163.30 \mathrm{de}$ & $205.00 \mathrm{abcd}$ \\
\hline $\mathbf{0}$ & 30 & 30 & $295.50 \mathrm{~d}$ & $346.50 \mathrm{f}$ & $119.60 \mathrm{e}$ & $148.30 \mathrm{de}$ & $423.30 \mathrm{~d}$ & $305.60 \mathrm{~d}$ & $129.30 \mathrm{f}$ & $158.33 \mathrm{~cd}$ \\
\hline
\end{tabular}

Bakry and Wanas (2003), mentioned that spraying yeast extract had positively effect on fruit firmness of apricot.

\section{Number of Grains/Fruit}

As shown in Table 3 the number of grains per fruit was significantly affected by fertilization treatments in the two experimental seasons. The maximum number of grains per fruit (630.70 and 492.30 grain) was gained by the trees fertilized by 25 and $50 \%$ mineral + $30 \mathrm{~g}$ mycorrhiza/tree in the first and second seasons, respectively without significant differences between them, as well, those fertilized by $25 \%$ mineral $+30 \mathrm{~g}$ mycorrhiza /tree (484.20 grain) and those fertilized by $75 \%$ mineral $+30 \mathrm{ml}$ yeast extract or mycorrhiza/tree (448.00 and 447.30 grain) in the second season only. Whereas, the least number of grains per fruit was recorded for trees fertilized by $0 \%$ mineral $+30 \mathrm{~g}$ mycorrhiza $+30 \mathrm{ml}$ yeast extract/tree (346.50 and 305.60 grain) in the two seasons. The trees fertilized by $75 \%$ mineral $+30 \mathrm{~g}$ mycorrhiza $+30 \mathrm{ml}$ yeast extract/ tree and the trees fertilized by 50 or $25 \%$ mineral $+30 \mathrm{~g}$ mycorrhiza $+30 \mathrm{ml}$ yeast extract/tree gave in between values without significant differences among them in both seasons. The other treatments gained intermediate values without significant differences among them in most cases in both seasons.

Similar results were found by Abd ElMonem et al. (2008), Hashem et al. (2008) and Fawzi et al. (2014) on grapevine. They found that berry numbers were significantly increased by yeast extract strains.

\section{Grains Weight}

Results in Table 3 show that grains weight (g) was significantly affected by the studied fertilization treatments in the two seasons of study. The highest grains weight of fruit was gained by the trees fertilized by $25 \%$ mineral + $30 \mathrm{~g}$ mycorrhiza /tree (227.70 and $213.50 \mathrm{~g})$ in the first and second seasons, respectively. The trees fertilized by 75 or $25 \%$ mineral $+30 \mathrm{ml}$ yeast extract/tree (206.60 and $197.10 \mathrm{~g})$, respectively, without significant differences between them in the second season, respectively. While, the lowest weight of grains per fruit was 
recorded for trees fertilized by $0 \%$ mineral + $30 \mathrm{~g}$ mycorrhiza $+30 \mathrm{ml}$ yeast extract/ tree $(119.60$ and $129.30 \mathrm{~g})$ in the two seasons. The other treatments gained intermediate values without significant differences among them in most cases in both seasons.

Abd El-Monem et al. (2008), Hashem et al. (2008) and Fawzi et al. (2014) on grapevine found that berry weight was significantly increased by yeast extract.

\section{Fruit Juice Volume}

It is quite evident from Table 3 that fruit juice volume $\left(\mathrm{cm}^{3}\right)$ was significantly affected by the experimented fertilization treatments in the two seasons. Trees fertilized by $75 \%$ mineral + $30 \mathrm{~g}$ mycorrhiza/tree gained the maximum fruit juice volume $\left(240.00\right.$ and $\left.256.66 \mathrm{~cm}^{3}\right)$ in the $1^{\text {st }}$ and $2^{\text {nd }}$ seasons, respectively without significant differences between them and those treated by $50 \%$ (213.30 and $\left.206.66 \mathrm{~cm}^{3}\right), 25 \%$ (223.30 and $\left.243.33 \mathrm{~cm}^{3}\right)$ mineral $+30 \mathrm{~g}$ mycorrhiza / tree, and those fertilized by $100 \%$ mineral/tree (control) $\left(201.00\right.$ and $215.00 \mathrm{~cm}^{3}$ ) and those fertilized by $25 \%$ mineral $+30 \mathrm{ml}$ yeast extract/tree $\left(205.00\right.$ and $\left.215.00 \mathrm{~cm}^{3}\right)$ in both seasons. The other treatments gained intermediate fruit juice volume $\left(\mathrm{cm}^{3}\right)$ without significant differences among them in most cases in both seasons.

Similar results were found by Mohamed and Massoud (2017) on orange, who found that AM with Azotobacter promoted the fruit physical i.e., juice volume as compared to uninoculated control and biofertilizer only.

Bakry (2007) and El Shazly and Mustafa (2013) on orange showed that all biostimulants (yeast extract) increased fruit juice (\%).

\section{TSS/Acid Ratio}

Table 4 clarified that TSS/acid ratio in the fruit juice was significantly affected by the studied fertilization treatments in both seasons. The uppermost values of TSS/acid ratio were obtained from fruit juice of trees fertilized by $25 \%$ mineral $+30 \mathrm{~g}$ mycorrhiza/tree (34.27 and 32.49 ) in the first and second season, respectively. The lowermost values of TSS/acid ratio were obtained from fruit juice of trees fertilized by $50 \%$ mineral $+30 \mathrm{ml}$ yeast extract/tree (12.39) and those fertilized by $25 \%$ mineral $+30 \mathrm{~g}$ mycorrhiza $+30 \mathrm{ml}$ yeast extract/tree (12.52) in the first season without differences between them and with trees fertilized by $50 \%$ mineral + $30 \mathrm{~g}$ mycorrhiza / tree, while, in the second one were from fruit juice of trees fertilized by $50 \%$ mineral $+30 \mathrm{~g}$ mycorrhiza /tree (12.64) and trees fertilized by $50 \%$ mineral $+30 \mathrm{ml}$ yeast extract/ tree (10.45). The other treatments gained intermediate values of fruit juice TSS/acid ratio without significant differences among them in both seasons.

These results are in line with those reported by Mohamed and Massoud (2017) on orange, they indicated that, using mycorrhiza with Azotobacter promoted the fruit chemical properties i.e., TSS/acid ratios as compared to uninoculated control and biofertilizer only.

Nomier (2000), Hegab et al. (2010), ElSabagh et al. (2011) and Sabry et al. (2013) on grapevine, Abdel-Mohsen and Kamel (2015) on apricot and El-Sehrawy (2015) on apple, they mentioned that active dry yeast extract increased TSS/acid ratio.

\section{Vitamin $C$ content}

As shown in Table 4 ascorbic acid (vitamin C) content in pomegranate fruit juice was significant affected by the tested fertilization treatments in the two seasons. However, fruits produced on trees fertilized by $75 \%$ mineral + $30 \mathrm{~g}$ mycorrhiza $+30 \mathrm{ml}$ yeast extract/tree $(0.010 \mathrm{mg} / 100 \mathrm{ml})$ contained the highest vitamin $\mathrm{C}$ content in the first season without significant differences with those fertilized by $100 \%$ mineral, 25 or $50 \%$ mineral $+30 \mathrm{~g}$ mycorrhiza / tree, $75 \%$ mineral $+30 \mathrm{ml}$ yeast extract/ tree and $25 \%$ mineral $+30 \mathrm{ml}$ yeast extract and $30 \mathrm{~g}$ mycorrhiza. In the second season the highest values came for trees fertilized by 50 or $25 \%$ mineral +30 g mycorrhiza /tree without significant differences with all treatments except those fertilized by $0 \%$ mineral +30 g mycorrhiza + $30 \mathrm{ml}$ yeast extract/tree which recorded the lowermost vitamin $\mathrm{C}$ content.

Similar results were stated by Abd-Ella (2006) who found that using microbial biofertilization (AM) on pomegranate trees did not affect vitamin $\mathrm{C}$ contents. The first treatment (trees 
Table 4. Effect of mineral fertilizers with mycorrhiza and yeast extract treatments on some fruit chemical constituents of Manfaloty pomegranate trees (2015 and 2016 seasons)

\begin{tabular}{ccccccccc}
\hline Fertilization treatment & \multicolumn{3}{c}{ First season (2015) } & \multicolumn{3}{c}{ Second season (2016) } \\
\hline $\begin{array}{c}\text { Mineral } \\
\mathbf{( \% )}\end{array}$ & $\begin{array}{c}\mathbf{A M} \\
\text { (g/ } \\
\text { tree) }\end{array}$ & $\begin{array}{c}\text { Yeast } \\
\text { extract } \\
(\mathbf{m l} / \text { tree })\end{array}$ & $\begin{array}{c}\text { Vitamin C } \\
(\mathbf{m g} / \mathbf{1 0 0} \\
\mathbf{m l})\end{array}$ & $\begin{array}{c}\text { TSS/ } \\
\text { acid } \\
\text { ratio }\end{array}$ & $\begin{array}{c}\text { Total } \\
\text { anthocyanin } \\
\text { content }(\%)\end{array}$ & $\begin{array}{c}\text { Vitamin C } \\
(\mathbf{m g} / \mathbf{1 0 0} \\
\mathbf{m l})\end{array}$ & $\begin{array}{c}\text { TSS/ } \\
\text { acid } \\
\text { ratio }\end{array}$ & $\begin{array}{c}\text { Total } \\
\text { anthocyanin } \\
\text { content (\%) }\end{array}$ \\
\hline $\mathbf{1 0 0}$ & $\mathbf{0}$ & $\mathbf{0}$ & $0.009 \mathrm{ab}$ & $14.90 \mathrm{bcd}$ & $22.60 \mathrm{i}$ & $0.009 \mathrm{ab}$ & $15.51 \mathrm{bc}$ & $23.75 \mathrm{j}$ \\
$\mathbf{7 5}$ & $\mathbf{3 0}$ & $\mathbf{0}$ & $0.004 \mathrm{c}$ & $30.56 \mathrm{abc}$ & $31.36 \mathrm{~b}$ & $0.007 \mathrm{ab}$ & $30.39 \mathrm{ab}$ & $32.44 \mathrm{~b}$ \\
$\mathbf{5 0}$ & $\mathbf{3 0}$ & $\mathbf{0}$ & $0.007 \mathrm{abc}$ & $14.34 \mathrm{~cd}$ & $29.57 \mathrm{~d}$ & $0.010 \mathrm{a}$ & $12.64 \mathrm{c}$ & $30.79 \mathrm{~d}$ \\
$\mathbf{2 5}$ & $\mathbf{3 0}$ & $\mathbf{0}$ & $0.007 \mathrm{abc}$ & $34.27 \mathrm{a}$ & $32.42 \mathrm{a}$ & $0.011 \mathrm{a}$ & $32.49 \mathrm{a}$ & $33.17 \mathrm{a}$ \\
$\mathbf{7 5}$ & $\mathbf{0}$ & $\mathbf{3 0}$ & $0.006 \mathrm{abc}$ & $16.59 \mathrm{bcd}$ & $29.56 \mathrm{~d}$ & $0.007 \mathrm{ab}$ & $24.79 \mathrm{abc}$ & $30.27 \mathrm{e}$ \\
$\mathbf{5 0}$ & $\mathbf{0}$ & $\mathbf{3 0}$ & $0.005 \mathrm{bc}$ & $12.39 \mathrm{~d}$ & $27.50 \mathrm{f}$ & $0.009 \mathrm{ab}$ & $10.45 \mathrm{c}$ & $28.94 \mathrm{~g}$ \\
$\mathbf{2 5}$ & $\mathbf{0}$ & $\mathbf{3 0}$ & $0.005 \mathrm{bc}$ & $20.33 \mathrm{a}-\mathrm{d}$ & $30.74 \mathrm{c}$ & $0.007 \mathrm{ab}$ & $17.78 \mathrm{abc}$ & $31.95 \mathrm{c}$ \\
$\mathbf{7 5}$ & $\mathbf{3 0}$ & $\mathbf{3 0}$ & $0.010 \mathrm{a}$ & $31.92 \mathrm{ab}$ & $26.56 \mathrm{~g}$ & $0.009 \mathrm{ab}$ & $24.32 \mathrm{abc}$ & $27.57 \mathrm{~h}$ \\
$\mathbf{5 0}$ & $\mathbf{3 0}$ & $\mathbf{3 0}$ & $0.005 \mathrm{bc}$ & $30.59 \mathrm{abc}$ & $25.28 \mathrm{~h}$ & $0.007 \mathrm{ab}$ & $18.18 \mathrm{abc}$ & $26.10 \mathrm{i}$ \\
$\mathbf{2 5}$ & $\mathbf{3 0}$ & $\mathbf{3 0}$ & $0.007 \mathrm{abc}$ & $12.52 \mathrm{~d}$ & $28.62 \mathrm{e}$ & $0.006 \mathrm{ab}$ & $16.87 \mathrm{abc}$ & $29.74 \mathrm{f}$ \\
$\mathbf{0}$ & $\mathbf{3 0}$ & $\mathbf{3 0}$ & $0.004 \mathrm{c}$ & $30.23 \mathrm{abc}$ & $26.64 \mathrm{~g}$ & $0.005 \mathrm{~b}$ & $25.50 \mathrm{abc}$ & $27.50 \mathrm{~h}$ \\
\hline
\end{tabular}

Means having the same letter (s) in each column are insignificantly different.

$\mathrm{AM}=$ mycorrhiza

were microbial inoculation and received $100 \%$ of the recommended doses of chemical fertilizers) had a slight increase in vitamin $\mathrm{C}$ content in both seasons.

Khafagy et al. (2010) concluded that spraying of Navel orange trees with $4.0 \%$ yeast extract combined with $1.0 \%$ zinc sulphate recorded the highest values of ascorbic acid.

El-Shazly and Mustafa (2013) on orange, they cleared that vitamin $\mathrm{C}$ contents markedly increased with biostimulants (potassium humate, yeast extract and amino acid) treatments compared to control.

\section{Total Anthocyanin Content}

Results in Table 4 clear that the studied fertilization treatments significantly affected juice total anthocyanin content (\%) in the two seasons. The highest juice total anthocyanin content was gained from fruits produced on trees fertilized by $25 \%$ mineral $+30 \mathrm{~g}$ mycorrhiza/tree (32.42 and 33.17\%) in both seasons. While, lowermost juice total anthocyanin content (\%) was recorded from fruits produced on trees fertilized by $100 \%$ mineral (control) $(22.60$ and $23.75 \%$ ) in the two seasons. The other tested fertilization treatments, recorded inbetween values in both seasons.

These results are in agreement with those stated by Abd-Ella (2006) who reported that, microbial inoculation of pomegranate trees with (AM) and received $75 \%$ of the recommended doses of chemical fertilizers recorded the highest juice anthocyanin content.

Hegab et al. (2010), Sabry et al. (2013) and Masoud and Abou-Zaid (2017) on grapevine, mentioned that using yeast extract enhancing anthocyanins content in berry skin and increased berry color.

Bakry and Wanas (2003) found that apricot fruit quality measurements positively responded to the application of yeast extract and kinetin treatments. In addition, all applied yeast extract and kinetin treatments increased leaf photosynthetic pigments content during the stages of fruit development. 


\section{Leaf Mineral Content}

Results presented in Table 5 reveal that the tested fertilization treatments significantly affected leaf $\mathrm{N}, \mathrm{P}$ and $\mathrm{K}$ percentages in both seasons. The highest values of N\% (2.47 and $2.68 \%), \mathrm{P} \%$ (0.287 and $0.296 \%)$ and $\mathrm{K} \%$ (3.35 and $3.24 \%$ ) resulted from the trees fertilized by $100 \%$ mineral/tree (control) in the first and second seasons, respectively. On the other hand, the lowermost values of $\mathrm{N} \%(1.55$ and $1.51 \%)$, $\mathrm{P} \%(0.237$ and $0.229 \%)$ and $\mathrm{K} \%$ (2.54 and $2.20 \%$ ) came from the trees fertilized by $0 \%$ mineral $+30 \mathrm{~g}$ mycorrhiza $+30 \mathrm{ml}$ yeast extract/ tree in the first and second seasons respectively. The other treatments gave intermediate values without significant differences among them in some cases.

Results in Table 6 clear that the tested fertilization treatments significantly affected $\mathrm{Ca}$ and $\mathrm{Mg}$ percentages in the leaves of pomegranate trees cv. Manfaloty throughout the two seasons. The highest values of $\mathrm{Ca} \%(2.71$ and $2.74 \%$ ) and $\mathrm{Mg} \%$ (0.975 and $0.979 \%)$ resulted from the trees fertilized by $100 \%$ mineral/tree (control) in the first and second seasons, respectively. Whereas, the trees fertilized by $0 \%$ mineral $+30 \mathrm{~g}$ mycorrhiza + $30 \mathrm{ml}$ yeast extract/tree recorded the least values of $\mathrm{Ca} \%$ (1.80 and $1.70 \%)$ and $\mathrm{Mg} \%$ (0.777 and $0.662 \%)$ in both seasons. The other treatments gave intermediate values without significant differences among them in some cases.

These results are in consistent with those obtained by Alok and Singh (2004) and Rodríguez-Romero et al. (2005) on banana, Abd Ella (2006) on Arabi pomegranate, QiangSheng and Ying-Ning (2009) on trifoliate orange, Dutt et al. (2013) on apricot, Merwad et al. (2014) on Valencia orange, Ortas and Ustuner (2014) on sour orange, Hosseini and Gharaghani (2015) on apple, Trouvelot et al. (2015) on grapevine, Chen et al. (2017) on trifoliate orange, Mohamed and Massoud (2017) on orange, Salama et al. (2017) on Washington navel orange, Soliman et al. (2017) on peach, they indicated that, mineral fertilization improved leaf-macro and micronutrients contents.

Table 5. Effect of mineral fertilizers with mycorrhiza and yeast extract treatments on leaf mineral content (N, P, K, Ca and Mg) of Manfaloty pomegranate trees (2015 and 2016 seasons)

\begin{tabular}{ccccccccc}
\hline Fertilization treatment & \multicolumn{3}{c}{ First season (2015) } & \multicolumn{3}{c}{ Second season (2016) } \\
\hline $\begin{array}{c}\text { Mineral } \\
\mathbf{( \% )}\end{array}$ & $\begin{array}{c}\mathbf{A M} \\
(\mathbf{g} / \text { tree) }\end{array}$ & $\begin{array}{c}\text { Yeast } \\
\text { extract } \\
\text { (ml/tree) }\end{array}$ & $\begin{array}{c}\mathbf{N} \\
\mathbf{( \% )}\end{array}$ & $\begin{array}{c}\mathbf{P} \\
\mathbf{( \% )}\end{array}$ & $\begin{array}{c}\mathbf{K} \\
\mathbf{( \% )}\end{array}$ & $\begin{array}{c}\mathbf{N} \\
\mathbf{( \% )}\end{array}$ & $\begin{array}{c}\mathbf{P} \\
\mathbf{( \% )}\end{array}$ & $\begin{array}{c}\mathbf{K} \\
\mathbf{( \% )}\end{array}$ \\
\hline $\mathbf{1 0 0}$ & $\mathbf{0}$ & $\mathbf{0}$ & $2.47 \mathrm{a}$ & $0.287 \mathrm{a}$ & $3.35 \mathrm{a}$ & $2.68 \mathrm{a}$ & $0.296 \mathrm{a}$ & $3.24 \mathrm{a}$ \\
$\mathbf{7 5}$ & $\mathbf{3 0}$ & $\mathbf{0}$ & $2.04 \mathrm{~b}$ & $0.274 \mathrm{~b}$ & $3.09 \mathrm{~b}$ & $2.23 \mathrm{~b}$ & $0.279 \mathrm{~b}$ & $3.18 \mathrm{a}$ \\
$\mathbf{5 0}$ & $\mathbf{3 0}$ & $\mathbf{0}$ & $1.89 \mathrm{bc}$ & $0.267 \mathrm{c}$ & $2.87 \mathrm{c}$ & $2.04 \mathrm{c}$ & $0.271 \mathrm{c}$ & $2.74 \mathrm{~b}$ \\
$\mathbf{2 5}$ & $\mathbf{3 0}$ & $\mathbf{0}$ & $1.81 \mathrm{cde}$ & $0.261 \mathrm{~d}$ & $2.85 \mathrm{c}$ & $1.92 \mathrm{~d}$ & $0.263 \mathrm{~d}$ & $2.73 \mathrm{~b}$ \\
$\mathbf{7 5}$ & $\mathbf{0}$ & $\mathbf{3 0}$ & $1.73 \mathrm{cdef}$ & $0.273 \mathrm{bc}$ & $2.78 \mathrm{~cd}$ & $1.80 \mathrm{e}$ & $0.257 \mathrm{de}$ & $2.60 \mathrm{~cd}$ \\
$\mathbf{5 0}$ & $\mathbf{0}$ & $\mathbf{3 0}$ & $1.84 \mathrm{~cd}$ & $0.255 \mathrm{de}$ & $2.72 \mathrm{~d}$ & $1.68 \mathrm{f}$ & $0.256 \mathrm{de}$ & $2.69 \mathrm{bc}$ \\
$\mathbf{2 5}$ & $\mathbf{0}$ & $\mathbf{3 0}$ & $1.79 \mathrm{cde}$ & $0.252 \mathrm{e}$ & $2.59 \mathrm{ef}$ & $1.66 \mathrm{fg}$ & $0.250 \mathrm{e}$ & $2.62 \mathrm{~cd}$ \\
$\mathbf{7 5}$ & $\mathbf{3 0}$ & $\mathbf{3 0}$ & $1.76 \mathrm{cde}$ & $0.240 \mathrm{f}$ & $2.90 \mathrm{c}$ & $1.77 \mathrm{ef}$ & $0.236 \mathrm{fg}$ & $2.55 \mathrm{~d}$ \\
$\mathbf{5 0}$ & $\mathbf{3 0}$ & $\mathbf{3 0}$ & $1.65 \mathrm{def}$ & $0.238 \mathrm{f}$ & $2.69 \mathrm{de}$ & $1.49 \mathrm{~h}$ & $0.240 \mathrm{f}$ & $2.39 \mathrm{e}$ \\
$\mathbf{2 5}$ & $\mathbf{3 0}$ & $\mathbf{3 0}$ & $1.61 \mathrm{ef}$ & $0.242 \mathrm{f}$ & $2.55 \mathrm{f}$ & $1.56 \mathrm{gh}$ & $0.235 \mathrm{fg}$ & $2.42 \mathrm{e}$ \\
$\mathbf{0}$ & $\mathbf{3 0}$ & $\mathbf{3 0}$ & $1.55 \mathrm{f}$ & $0.237 \mathrm{f}$ & $2.54 \mathrm{f}$ & $1.51 \mathrm{~h}$ & $0.229 \mathrm{~g}$ & $2.20 \mathrm{f}$ \\
\hline
\end{tabular}

Means having the same letter (s) in each column are insignificantly different. $\mathrm{AM}=$ mycorrhiza. 
Table 6. Effect of mineral fertilizers with mycorrhiza and yeast extract treatments on leaf mineral content of Manfaloty pomegranate trees (2015 and 2016 seasons)

\begin{tabular}{|c|c|c|c|c|c|c|}
\hline \multicolumn{3}{|c|}{ Fertilization treatments } & \multicolumn{2}{|c|}{ First season (2015) } & \multicolumn{2}{|c|}{ Second season (2016) } \\
\hline $\begin{array}{c}\text { Mineral } \\
(\%)\end{array}$ & $\begin{array}{c}\text { AM } \\
\text { (g/tree) }\end{array}$ & $\begin{array}{c}\text { Yeast extract } \\
\text { (ml/tree) }\end{array}$ & $\begin{array}{l}\mathrm{Ca} \\
(\%)\end{array}$ & $\begin{array}{l}\mathrm{Mg} \\
(\%)\end{array}$ & $\begin{array}{c}\mathrm{Ca} \\
(\%)\end{array}$ & $\begin{array}{l}\text { Mg } \\
(\%)\end{array}$ \\
\hline 100 & $\mathbf{0}$ & $\mathbf{0}$ & $2.71 \mathrm{a}$ & $0.975 \mathrm{a}$ & $2.74 \mathrm{a}$ & $0.979 \mathrm{a}$ \\
\hline 75 & 30 & $\mathbf{0}$ & $2.58 \mathrm{~b}$ & $0.937 \mathrm{~b}$ & $2.69 \mathrm{a}$ & $0.948 \mathrm{~b}$ \\
\hline 50 & 30 & $\mathbf{0}$ & $2.40 \mathrm{~d}$ & $0.917 \mathrm{c}$ & $2.45 \mathrm{~b}$ & $0.931 \mathrm{c}$ \\
\hline 25 & 30 & $\mathbf{0}$ & $2.30 \mathrm{e}$ & $0.903 \mathrm{~d}$ & $2.41 \mathrm{~b}$ & $0.933 \mathrm{c}$ \\
\hline 75 & $\mathbf{0}$ & 30 & $2.50 \mathrm{c}$ & $0.887 \mathrm{e}$ & $2.40 \mathrm{~b}$ & $0.882 \mathrm{e}$ \\
\hline 50 & $\mathbf{0}$ & 30 & $2.16 \mathrm{f}$ & $0.888 \mathrm{e}$ & $2.15 \mathrm{c}$ & $0.871 \mathrm{e}$ \\
\hline 25 & $\mathbf{0}$ & 30 & $2.06 \mathrm{~g}$ & $0.869 \mathrm{f}$ & $1.91 \mathrm{e}$ & $0.880 \mathrm{e}$ \\
\hline 75 & 30 & 30 & $1.89 \mathrm{~h}$ & $0.883 \mathrm{e}$ & $1.90 \mathrm{e}$ & $0.839 \mathrm{f}$ \\
\hline 50 & 30 & 30 & $2.01 \mathrm{~g}$ & $0.829 \mathrm{~g}$ & $2.08 \mathrm{~d}$ & $0.905 \mathrm{~d}$ \\
\hline 25 & 30 & 30 & $1.85 \mathrm{hi}$ & $0.809 \mathrm{~h}$ & $1.76 \mathrm{f}$ & $0.803 \mathrm{~g}$ \\
\hline 0 & 30 & 30 & $1.80 \mathrm{i}$ & $0.777 \mathrm{i}$ & $1.70 \mathrm{~g}$ & $0.662 \mathrm{~h}$ \\
\hline
\end{tabular}

Means having the same letter (s) in each column are insignificantly different.

Soliman et al. (2017) on peach, they indicated that using mycorrhiza decreased leaf$\mathrm{Na}$, as compared to that of the control. Also, Mycorrhiza was superior to leaf-P and $\mathrm{Mg}$ contents.

The mycorrhiza fungi can be benefit to plants by enhancing the availability and uptake of soil water and nutrients (Smith and Read, 1997; Abdul Malik, 2000).

Masoud and Abou-Zaid (2017) on grapevines, El-Sayed (2013) on olive, El-Shazly and Mustafa (2013) on orange, Mohsen et al. (2014), Abd El-Rahman and Mansour (2015) on banana, El-Sehrawy (2015) on apple, Kamel (2015) on pomegranate, Haggag et al. (2015) on olive, Shaaban et al. (2015) on apricot, AbdelRahman and Tolba (2016) on grapevine, Masoud and Abou-Zaid (2017) on grapevine. They cleared that application of yeast extract enhanced and increased leaf mineral contents.

\section{REFERENCES}

Abd El-Galil, H.A., M.M. El-Dsouky and M.M. El-Wasfy (2003). Effect of some cultural practices on "King's Ruby" grapevines production under Assuit conditions. AEffect of organic manure and yeast extract applications on growth and nutrient status as well as yield and berry quality. Assuit $\mathrm{J}$. Agric. Sci., 34 (6):173-192.

Abd Ella, E.E.S.K. (2006). Effect of biofertilization on reducing chemical fertilizers, vegetative growth, nutritional status, yield and fruit quality of Arabi pomegranate trees. Hort. Res. Station. Sabahia, Alex., Hort. Res. Ins. ARC, Egypt.

Abd El-Monem, E.A.A., M.M.S. Saleh and E.A.M. Mostafa (2008). Minimizing the quantity of mineral nitrogen fertilizers on grapevine by using humic acid, organic and biofertilizers. Res. J. Agric. and Biol. Sci., 4 (1): 46-50.

Abd El-Moniem, A.A., S.E. Eman, A.M. Gomaa and R.G. Stino (2002). Effect of spraying with boric acid, GA3, Amactone, activated yeast extract and source on Abd El-Razik annona fruit set and quality. Zagazig $\mathrm{J}$. Agric., 29 (5): 1579-1590. 
Abd El-Motty, E.Z., F.M.M. Shahin, H.M. ElShiekh and M.M.M. Abd El-Migeed (2010). Effect of algae extract and yeast extract application on growth, nutritional status, yield and fruit quality of Keitte mango trees. Agric. Biol. J. N. Am., 1 (3): 421-429.

Abd El-Rahman, M.M.A. and A.E.M. Mansour (2015). Response of williams banana plants to application of EM1 and yeast extract. Middle East J. Agric., 4 (2): 277-282.

Abdel-Mohsen, M.A. and H.M. Kamel (2015). Fruit set and quality of 'Canino' apricot fruits as affected by spraying with yeast extract, growth regulators and micronutrients. J. Plant Prod., Mansoura Univ., 6 (8): 1431 1441.

Abdel-Rahman, A.S. and H.I. Tolba (2016). Possibility of improving growth, yield and bunch quality of Ruby Seedless grapevines through the application of yeast extract and summer pruning practice. Nat. Sci., 14 (2): 97-106.

Abdul Jaleel, C., R. Gopi, B. Sankar, P. Manivannan, A. Kishorekumar, R. Sridharan and R. Panneerselvam (2007). Studies on germination, seedling vigour, lipid peroxidation and proline metabolism in Catharanthus roseus seedlings under salt stress. South Afr. J. Bot., 73 (2): 190-195.

Abdul Mallik, M. (2000). Association of arbuscular mycorrhizae with some varieties of Tobacco (Nicotiana tobacum L.) and its effect on their growth, nutrition and certain soilborne diseases, Ph.D. Thesis, Bharathidasan Univ., Tiruchirapalli, S. India, 104.

Alok, S. and S.P. Singh (2004). Response of banana (Musa sp.) to vesicular arbuscular mycorrhiza and varied levels of inorganic fertilizers. Indian J. Hort., 61 (2): 109 - 113.

AOAC (2006) Official Methods of Analysis of the Association of Official Agricultural Chemists. $16^{\text {th }}$ Ed., Washington, DC, USA.

Arines, J. and A. Ballester (1992). Mycorrhization of micropropagated Prunus avium L. plantlets. In: Micropropagation, Root Regeneration, and Mycorrhizas. P 45. Joint
Meeting Between COST 87 and COST 8.10, Dijon, France.

Aseri , G.K., N. Jain, J. Panwar, A.V. Rao and P.R. Meghwal (2008). Biofertilizers improve plant growth, fruit yield, nutrition, metabolism and rhizosphere enzyme activities of pomegranate (Punica granatum L.) in Indian Thar Desert. Sci. Hort., 117 : 130-135.

Attala, E.S., A.M. El-Seginy and G.T. Eliwa (2000). Response of Le conte pear trees to foliar applications with active dry yeast extract. J. Agric. Sci. Mansoura Univ., 25 (12): 8005-8011.

Bakry, K.A. (2007). Response of Jaffa orange cultivar to spray with yeast extract and promalin. Egypt. J. Appl. Sci., 22 (10A): 195-210.

Bakry, K.A. and A.L. Wanas (2003). Response of Amar apricot trees to spray with yeast extract and Kinetin. Egypt J. Appl. Sci., 18 (6) : 319 - 336.

Barnett, J.A., R.W. Payne and D. Yarrow (1990). Yeast Extract Characteristics and Identification. Cambridge Univ. Press, London, 999.

Branzanti, B., V. Gianinazzi-Pearson and S. Gianinazzi (1992). Influence of phosphate fertilization on the growth and nutrient status of micropropagated apple infected with endomycorrhizal fungi during the weaning stage. Agron., 12 (10): 841-845.

Chen, Y.Y., Y.C. Hu and J.X. Xiao (2017). Effects of arbuscular mycorrhizal fungi on the growth and zinc uptake of trifoliate orange (Poncirus trifoliata) seedlings grown in low-zinc soil. J. P1. Nutr., 40 (3): 324-331.

Duncan, D.B. (1958). Multiple Rang and Multiple F test. Biomet., 11: 1-42.

Dutt, S., S.D. Sharma and P. Kumar (2013). Arbuscular mycorrhizas and $\mathrm{Zn}$ fertilization modify growth and physiological behavior of apricot (Prunus armeniaca L.). Sci. Hort., 155: 97-104.

El-Sabagh, A.S., F.M. El-Morsy and A.R. Farag (2011). Effect of biofertilizers as a partial substitute for nitrogen fertilzier on vegetative growth, yield, fruit quality and leaf mineral 
content of two seedless grape cultivars II: fruit quality and leaf mineral content. J. Hort. Sci. and Ornamen. Plants, 3 (2): 176-187.

El-Sayed, O.M. (2013). Improvement of aggizy olive trees productivity in saline calcarious soils using active dry yeast extract and humic acid. Res. J. Agric. and Biol. Sci., 9 (5): 136144.

El-Sehrawy, O.A.M. (2015). Reducing the amount of nitrate and nitrite in Anna apple fruits by using inorganic $\mathrm{N}$ along with $\mathrm{EM}$, yeast extract and humic acid. Alex. Sci. Exc. J., 36 (2): 188-196.

El-Shamma, M.S., E.M. Helal, M.M.A. Maksoud, F.H. Khalil and A.E.M. Mansour (2017). Effect of some bio - stimulants on nutritional status, yield and fruit quality of avocados. Middle East J. Agric. Res., 6 (3): 692-699.

El-Shazly, S.M. and N.S. Mustafa (2013). Enhancement yield, fruit quality and nutritional status of Washington Navel orange trees by application of biostimulants. J. Appl. Sci. Res., 9 (8): 5030-5034.

Evenhuis, B. and P.W. De Waard (1980). Principle and practies in plant analysis FAO Soils Bell., 38 (1): 152-163.

Fawzi, M.I.F., L.F. Haggag, M.F.M. Shahin, M.A. Merwad and E.A.E. Genaidy (2014). Influence of spraying urea, born, and active dry yeast extract on growth, yield, leaf chemical composition and fruit quality of "Superior" grapevines grown in sandy soil conditions. Middle East J. Appl. Sci., 3 (3): 740-747.

Gąstoł, M. and I. Domagała-Świątkiewicz (2015). Mycorrhizal inoculation of apple in replant soils-enhanced tree growth and mineral nutrient status. Acta Sci. Pol. Hortorum Cultus, 14 (4) : 17-37.

Geza, H., G. F. Parsons and L. R. Mattick. 1983. Physiological and biochemical events during development and maturation of grapes berry. Amer. J. Enol. Vitic., 35 (4): 220 - 227.

Haggag, L.F.E., A.E. Genaidy, M.F.M. Shahin, M.M.M. Mahdy, H.A. Amira, A. Fouad and
E.S. El-Hady (2015). Effect of NPK and yeast extract on "Manzanillo" olive seedlings growth under greenhouse conditions. Middle East J. Agric. Res., 4(4): 629-636.

Hashem, M., Y.A.M.M. Omran and N.M.A. Sallam (2008). Efficacy of yeast extracts in the management of root-knot nematode (Meloidogyne incognita), in Flame Seedless grape vines and the consequent effect on the productivity of the vines. J. Biocontrol Sci. and Technol., 18 (4): 357-375 .

Hegab, M.M., M.I.F. Fawzi and N.E. Ashour (2010). Effect of different yeast extract doses and time of application on growth, yield and quality of Ruby seedless grapevines. Minia J. Agric. Res. and Dev., 30 (2): 231-242.

Hosseini, A. and A. Gharaghani (2015). Effects of arbuscular mycorrhizal fungi on growth and nutrient uptake of apple rootstocks in calcareous soil. Int. J. Hort. Sci. and Technol., 2 (2): 173-185.

Jansa, J., A. Mazafar, G. Kuhum, A.T. Nken and E. Frossard (2003). Soil tillage affect the community structure of mycorrhiza fungi in maize root. Ecol. Applications, 13 : 11641176.

Kamel, H.M. (2015). Response of Manfalouty pomegranate transplants to foliar spray and soil drench applications with some natural extracts. J. Hortic. Sci. \& Ornamental Plants, 7 (3): 107-116.

Kamelia, I.A.A., F.M.A. Mostafa and T.K.A.A. El-Bolk (2000). Effect of yeast extract application on bud burst, physical and chemical characteristics of grape berries in "King Ruby" cultivar during growth stage2. Effect of applied yeast extract on physical and chemical characteristics of grape berries during growth stages. Assuit J. Agric. Sci., 31(4): 207-229.

Kannaiyan, S. (2002). Biotechnology of Biofertilizers. Alpha Sci. Inter. Ltd., PO Box 4067 Pangbourne R. 68 UK, 1-275.

Khafagy, S.A.A., N.S. Zaied, M.M. Nageib, M.A. Saleh and A.A. Fouad (2010).The beneficial effects of yeast extract and zinc sulphate on yield and fruit quality of navel 
orange trees. World J. Agric. Sci., 6 (6): 635638.

Kitson, R.E. and M.G. Mellon (1964). Colorimetric determination of phosphorus as molybdivanado phosphoric acid. 1nd-Eng. Chem. Anal. Ed., 16: 379-383.

Kohler, J., F. Caravaca, L. Carrasco and A. Rolden (2007). Interactions between a plant growth - promoting rhizobacterium , an AM fungus and phosphate-solublizing fungus in the rhizosphere of Lactuca sativa. Appl. Soil Ecol., 35: 480 - 487.

Koltai, H., V. Gadkar and Y. Kapulnik (2010). Biochemical and practical views of arbuscular mycorrhizal fungus-host association in hort. crops. Hort. Rev., 36: 257-287.

Lewis, J.D. and R.T. Koide (1990) Phosphorus supply, mycorrhizal infection and plant offspring vigour. Functional Ecol., 4: 695702.

Masoud, A.A.B. and E.A.A. Abou-Zaid (2017). Effects of spraying yeast extract, algae and fish oil on growth and fruiting of Ruby seedless grapevines. Assiut J. Agric. Sci., 48 (2): 104-114.

Merwad, M.M., M.S. El-Shamma, A.E.M. Mansour and M.E.M. Helal (2014). The effect of nitrogen fertilizer and mycorrhizal fungi on productivity of citrus trees grown in newly reclaimed soil. Middle East J. Agric. Res., 3 (3): 653-662.

Mohamed, S.A. and O.N. Massoud (2017). Impact of inoculation with mycorrhiza and azotobacter under different $\mathrm{N}$ and $\mathrm{P}$ rates on growth, nutrient status, yield and some soil characteristics of Washington Navel Orange Trees. Middle East J. Agric., 6 (3): 617-638.

Mohsen, A.T., M.A. Abdel-Mohsen, A.M. Ibrahim and A.S. Mostafa (2014). Effect of some stimulative substances on growth of two citrus rootstocks. J. Hort. Sci. and Ornamen. Plants, 6 (2): 90-99.

Mostafa, R.A.A. (2015). Effects of zinc, boron and active dry yeast extract sprays on yield and fruit quality of Zaghloul date palm. Arab Univ. J. Agric. Sci. Ain Shams Univ., 23 (2): 467-473.
Nagadawithana, W.T. (1991). Yeast extract Technology. Universal Foods Corporation Milwaukee. Wisconsin. Published by Van Nostrand Reinhold New York, 273.

Nomier, Safaa, (2000). Effect of some GA3, vitamins and active dry yeast extract treatments on vegetative growth, yield and fruit quality of Thompson seedless grapevines. Zagazig J. Agric. Res., 27 (5) 1267-1286.

Ortas, I. and O. Ustuner (2014). The effects of single species, dual species and indigenous mycorrhiza inoculation on citrus growth and nutrient uptake. European J. Soil Biol., 63: 64-69.

Osman, S.O.A., F.M.A. Moustafa, H.A. Abd ElGalil and A.Y.M. Ahmed (2011). Effect of yeast extract and effective microorganisms (Em1) application on the yield and fruit characteristics of Bartamuda date palm under Aswan conditions. The $5^{\text {th }}$ Conf. Young Sci. Fac. Agric. Assiut Univ., 42: 332-349.

Qiang-Sheng W.U. and Z.O.U. Ying-Ning (2009). The effect of dual application of arbuscular mycorrhizal fungi and polyamines upon growth and nutrient uptake on trifoliate orange (Poncirus trifoliata) seedlings. Not. Bot. Hort. Agrobot. Cluj., 37 (2) : 95-98.

Rodriguez-Romero, A.S., M.S. Pinero-Guerra and M.C. Jaizme-Vega (2005). Effect of arbuscular mycorrhizal fungi and rhizobacteria on banana growth and nutrition. Agron. Sustain. Dev., 25: 395-399.

Saber, S.M. (1993). Associative action of a multi-strain biofertilizer on tomato plants grain in newly reclaimed soils, proc. Sixth Int. symposium on Nitrogen fixation with nonlegumes, Ismailia, Egypt, 150.

Sabry, G.H., A.S. Abd El-Rahman and O.M. Fekry (2013). Role of yeast extract, ethephon and apple vinegar in improving fruit quality and storability of Flame seedless grape cultivar. Egypt. J. Hort., 40 (2): 143-171.

Salama, M.I., R.A. Sayed, A.R. El-Shereif and M.A. Mankolah (2017). Response of Washington navel orange trees to some soil amendments and foliar application of GA3 
under clay soil conditions. J. Sus. Agric. Sci. 43 (1): 39-54.

Shaaban, F.K.M., M.M. Morsey and T.Sh.M. Mahmoud (2015). Influence of spraying yeast extract and humic acid on fruitmaturity stage and storability of "Canino" apricot fruits. Int. J. Chem. Tech. Res., 8 (6): 530-543.

Sheets, M.D., M.L. Du Bois and J.G. Williamson (2008). The Pomegranate. Horticultural Sciences Department, Florida Cooperative Extension Service, Inst. Food and Agric., HS, 44: 1-3.

Singh S.K., G. Minakshi, R.N. Khawale, V.B. Patel, H. Krishna and A.K. Saxena (2004). Mycorrhization as an aid for biohardening of in vitro raised Grape (Vitis vinifera L.) plantlets. Acta Hort., 662: 289-295.

Singh, N.V., S.K. Sigh, A.K. Sigh, D.T. Meshram, S.S. Suroshe and D.C. Mishra (2012). Arbuscular mycorrhizal fungi (AMF) induced hardening of micropropagated pomegranate (Punica granatum L.) plantlets. Sci. Hort., 136: 122-127.

Smith, S.E. and D. J. Read (1997). Mycorrhiza Symbiosis. $2^{\text {nd }}$ Ed., Academic Press, London, 605.
Snedecor, G.W. and W.G. Cochran (1980). Statistical Methods. Oxford and JBH. publishing com. $7^{\text {th }}$ Ed., 593.

Soliman, M.A.M., H.M. Abo-Ogiela and N.A. El-Saedony (2017). Reducing adverse effects of salinity in peach trees grown in saline clay soil. Hort. Res. Inst. ARC. Giza, Egypt. Alex. Sci. Exch. J. 38 (4): 800-809.

Srivastava, A.K. (2012). Integrated nutrient management. In: Advances in Citrus Nutrition. A. K. Srivastava (Ed.) Springer Verlag, The Netherlands, $369-389$.

Stanley, M.R., R.T. Koide, D.L. Shumway (1993). Mycorrhizal symbiosis increases growth, reproduction and recruitment of Abutilon theophrasti Medic. In the field. Oecologia, $94: 30$ - 35 .

Statistics of the Ministry of Agriculture (2015). Statistics of fruit production.

Trouvelot, S., L. Bonneau, D. Redecker, D. van Tuinen, M. Adrian and D. Wipf (2015). Arbuscular mycorrhiza symbiosis in viticulture: a review. Agron. Sustain. Dev., $35: 1449-1467$.

\section{اتجــــاه لتقليـلـل كميـة الأسمدة المعدنية لأشجار الرمان المنقلوطي باستخدام الميكورهيزا والخميــرة \\ أحمد محمد عبد المحسن شعراوي ـ صفاء عبد الغتي أحمد نمير ـ محمد محمود إبراهيم ـ محمد ممتاز جاد

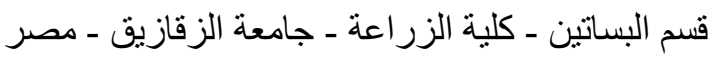

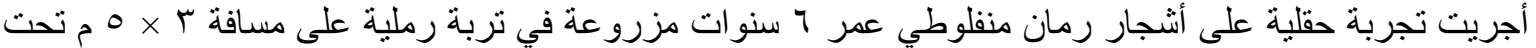

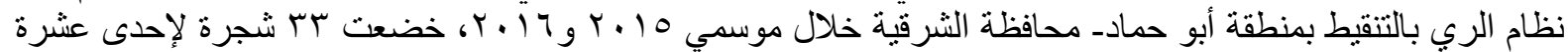

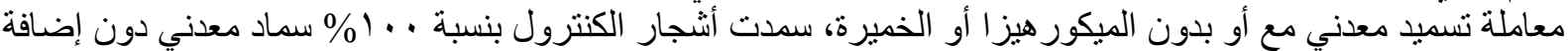

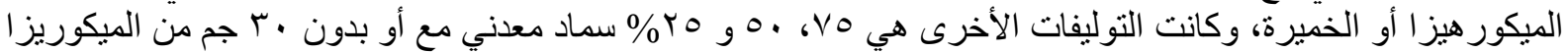

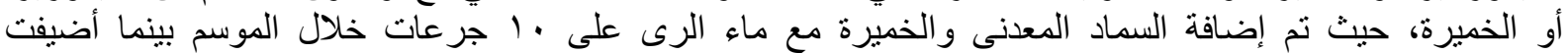

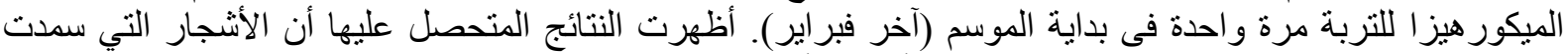

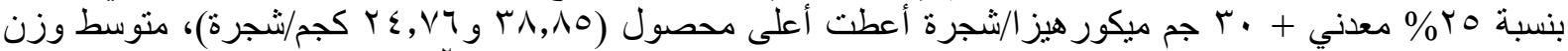

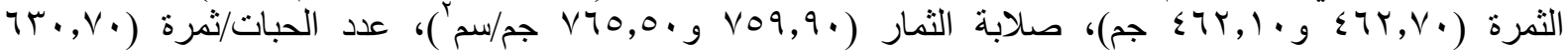

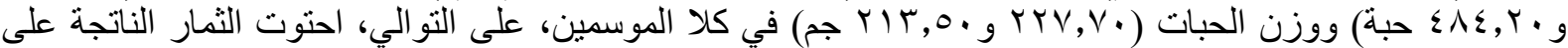

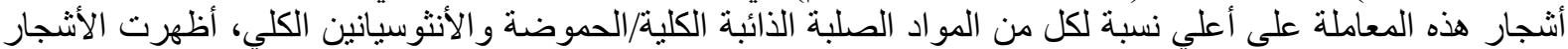

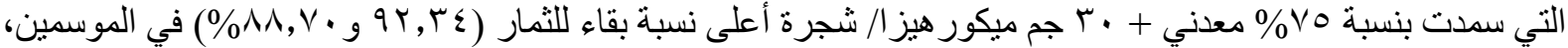

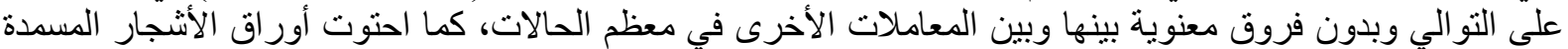

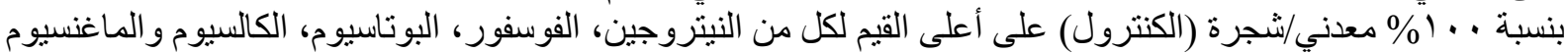

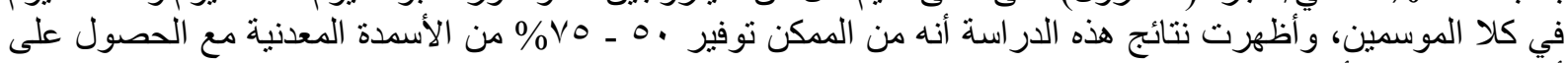

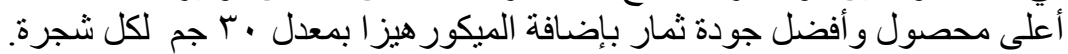

